\title{
Kinin $B_{1}$ receptors mediate depression-like behavior response in stressed mice treated with systemic $E$. coli lipopolysaccharide
}

\author{
Alice F Viana ${ }^{1 \dagger}$, Izaque S Maciel ${ }^{2 \dagger}$, Fabiana N Dornelles ${ }^{1}$, Claudia P Figueiredo ${ }^{1}$, Jarbas M Siqueira ${ }^{1}$,
} Maria M Campos ${ }^{3,4}$, João B Calixto ${ }^{1 *}$

\begin{abstract}
Background: Kinin $B_{1}$ receptors are inducible molecules up-regulated after inflammatory stimuli. This study evaluated the relevance of kinin $B_{1}$ receptors in a mouse depression behavior model.

Methods: Mice were exposed to a 5-min swimming session, and 30 min later they were injected with E. coli lipopolysaccharide (LPS). Depression-like behavior was assessed by determining immobility time in a tail suspension test. Different brain structures were collected for molecular and immunohistochemical studies. Anhedonia was assessed by means of a sucrose intake test.

Results: Our protocol elicited an increase in depression-like behavior in CF1 mice, as assessed by the tailsuspension test, at $24 \mathrm{~h}$. This behavior was significantly reduced by treatment with the selective $\mathrm{B}_{1}$ receptor antagonists R-715 and SSR240612. Administration of SSR240612 also prevented an increase in number of activated microglial cells in mouse hippocampus, but did not affect a reduction in expression of mRNA for brain-derived neurotrophic factor. The increased immobility time following LPS treatment was preceded by an enhancement of hippocampal and cortical $B_{1}$ receptor mRNA expression (which were maximal at $1 \mathrm{~h}$ ), and a marked production of TNF $\alpha$ in serum, brain and cerebrospinal fluid (between 1 and 6 h). The depression-like behavior was virtually abolished in TNF $\alpha$ p55 receptor-knockout mice, and increased $B_{1}$ receptor mRNA expression was completely absent in this mouse strain. Furthermore, treatment with SSR240612 was also effective in preventing anhedonia in LPS-treated mice, as assessed using a sucrose preference test.

Conclusion: Our data show, for the first time, involvement of kinin $B_{1}$ receptors in depressive behavioral responses, in a process likely associated with microglial activation and TNF $\alpha$ production. Thus, selective and orally active $B_{1}$ receptor antagonists might well represent promising pharmacological tools for depression therapy.
\end{abstract}

\section{Background}

Chronic depression represents a public health worldwide problem. Despite the existence of several drugs for depression treatment, these medicines have many significant adverse effects, and many patients do not display satisfactory responses to the current therapeutic arsenal [1]. The etiology of depression is incompletely understood, and this precludes development of more effective drugs. Compelling literature data suggests a crosstalk

\footnotetext{
* Correspondence: calixto@farmaco.ufsc.br

+ Contributed equally

'Pharmacology Department, Universidade Federal de Santa Catarina,

Florianópolis, SC, Brazil

Full list of author information is available at the end of the article
}

between immunological changes and major depression $[2,3]$. It has been demonstrated that systemic administration of pro-inflammatory cytokines or some bacterial products to rodents elicits a condition described as sickness behavior, characterized by decreased food consumption and locomotor activity, social isolation, and changes in the circadian cycle, which is followed by depressive behavior [3-5].

Toll-like receptors (TLR) are recognition units that distinguish microbial structures. Gram-negative bacterial lipopolysaccharide (LPS) commonly signals through TLR4, leading to activation of several intracellular pathways [6]. It has been demonstrated that depression-like
C Biomed Central

(C) 2010 Viana et al; licensee BioMed Central Ltd. This is an Open Access article distributed under the terms of the Creative Commons Attribution License (http://creativecommons.org/licenses/by/2.0), which permits unrestricted use, distribution, and reproduction in any medium, provided the original work is properly cited. 
behavior induced by LPS in rodents is dependent on cytokine production; importantly, depressed patients display elevated cytokine plasma levels [2,3]. Furthermore, it has been recently shown that TLR activation following infection can induce systemic inflammation, accompanied by signs of brain-controlled illness in rats $[7,8]$.

Kinins are a group of peptides that are rapidly generated in response to several stimuli [9]. Once released, kinins activate two $G$ protein-coupled receptors, called $B_{1}$ and $B_{2} . B_{2}$ receptors are constitutively expressed throughout several tissues, whereas $B_{1}$ receptors are not commonly expressed under normal conditions, although they are rapidly upregulated after infection, trauma, or by certain cytokines [10-13]. Of relevance, a series of previous publications has demonstrated an important role for TNFa in the up-regulation of kinin $B_{1}$ receptors [14-17]. Therefore, $B_{1}$ receptors are likely induced under certain pathological conditions, being involved in several chronic inflammatory and pain processes $[9,10]$.

Previous studies have demonstrated that LPS from either $E$. coli or $P$. gingivalis can induce a marked up-regulation of kinin $B_{1}$ receptors in animal models of peripheral inflammation, via cytokine production $[14,15,18]$. Of relevance, recent studies also suggest that kinin $B_{1}$ receptors have also been implicated in some diseases involving the central nervous system (CNS), such as epilepsy, Alzheimer's disease and neuropathic pain [19-21]. Taking into account the above mentioned data, the present study was designed to test the hypothesis that kinin $B_{1}$ receptors might be implicated in depression-like behavioral changes elicited by systemic administration of $E$. coli LPS, in mice submitted to a previous stressing forced swimming session. This experimental protocol was based on the concept that internal and external stressors are able to interact, culminating in a general illness state, which causes an allostatic overload [2,22,23]. Efforts have also been made to define some of the mechanisms responsible for $B_{1}$ receptor induction in the context of LPS-treated depressed animals by using biochemical and molecular techniques, such as flow cytometry, ELISA and real-time PCR. We have also aimed at determining whether antagonism of kinin $B_{1}$ receptors could modulate glial activity, throughout immunohistochemical studies. Finally, we further investigated the role played by TNF $\alpha$ in the depressive-like behavior in our experimental paradigm, by using TNF $\alpha$ p 55 receptor-deficient mice.

\section{Methods}

\section{Materials}

The following drugs and reagents were used: imipramine, LPS from E. coli serotype 0111:B4, aprotinin A, benzethonium chloride, EDTA, HTAB, hydrogen peroxide, PMSF, TMB and Tween-20 (all from Sigma Chemical Company St. Louis, U.S.A); R-715, kindly provided by Dr. Domenico
Regoli (University of Sherbrooke, Sherbooke, Quebec, Canada); SSR240612 was kindly provided by SanofiSynthelabo Recherche (Montpellier, France). FR173657 was donated by Fournier Laboratories (Dijon, France). The stock solutions of the drugs were prepared in PBS in siliconized plastic tubes, maintained at $-18^{\circ} \mathrm{C}$, and diluted to the desired concentration just before use.

\section{Animals}

Male CF1 and C57/BL6 wild-type, or TNF $\alpha$ p55 receptor knockout mice ( 25 to $30 \mathrm{~g}$ ) were used in this study. Animals were housed under conditions of optimum light, temperature and humidity ( $12 \mathrm{~h}$ light-dark cycle, $22 \pm 1^{\circ} \mathrm{C}$, under 60 to $80 \%$ humidity), with food and water provided ad libitum. CF1 mice were obtained from the central animal house of the Universidade Federal de Pelotas (UFPEL, Brazil). C57/BL6 wild-type, or TNF $\alpha$ p55 receptor knockout mice were supplied by the Universidade Federal de Minas Gerais (UFMG, Belo Horizonte, Brazil). All experiments were performed between 08:00 AM and 08:00 PM. Experiments were conducted in accordance with current guidelines for the care of laboratory animals and ethical guidelines for the investigation of experimental pain in conscious animals laid down by Zimmermann (1983) [24]. All the experimental procedures were approved by the Animal Ethics Committees of Universidade Federal de Santa Catarina (SC) and Pontifícia Universidade Católica do Rio Grande do Sul (RS).

\section{Induction of depressive-like behavior}

As a pre-stressful stimulus, the animals were subjected to forced swimming for $5 \mathrm{~min}$, in a water temperature of $23 \pm 1^{\circ} \mathrm{C}$. Subsequently, they were injected with LPS from E. coli (serotype 0111:B4) at the doses of $450 \mathrm{mg} /$ $\mathrm{kg}$ (CF1 mice) or $1000 \mu \mathrm{g} / \mathrm{kg}$ (C57/BL6 wild-type, or TNF $\alpha$ p55 receptor knockout mice), by i.p. route. The control groups received saline $(0.9 \% \mathrm{NaCl}$ solution, $10 \mathrm{ml} / \mathrm{kg}$, i.p.). The protocol of forced swimming and the selected doses of LPS were determined on the basis of pilot experiments (not shown).

The animals were assessed in behavioral paradigms at 6, 24 or 48 h time points after LPS administration, depending on the experimental protocol. All the behavioral parameters were evaluated by trained experimenters blind to the treatment groups. Separate groups of mice were euthanized at different time-points after LPS injection, in order to perform biochemical, molecular biology and immunohistochemical assays, as described in the next sections.

\section{Protocols of treatment with kinin antagonists}

To verify the involvement of kinin receptors in the behavioral changes elicited by LPS from E. coli, the animals were treated with one of the following drugs before 
behavioral tests: the selective antagonists of kinin $B_{1}$ receptor SSR240612 (5 mg/kg, i.p., $30 \mathrm{~min}$; or $10 \mathrm{mg} / \mathrm{kg}$, p.o., $1 \mathrm{~h}$ ) or R-715 (0.5 mg/kg, i.p., $30 \mathrm{~min})$, or the selective kinin $B_{2}$ receptor antagonist FR173657 (30 mg/kg, i.p., $30 \mathrm{~min})$. The classical tricyclic antidepressant imipramine (10 mg/kg, i.p., $30 \mathrm{~min}$ ) was used as a positive control drug. Control animals received saline solution $(0.9 \%$ $\mathrm{NaCl}$ solution, $10 \mathrm{ml} / \mathrm{kg}$ ), at the corresponding schedules of treatment used for the antagonists. For molecular biology and immunohistochemical studies, animals were treated with SSR240612 (5 mg/kg, i.p.), $30 \mathrm{~min}$ before LPS, and were sacrificed at defined time-points as described in the next sections. The doses of kinin antagonists and imipramine were determined on the basis of previous publications [25-27].

\section{Tail-suspension test}

To assess the depression-like behavior following the 5-min forced swimming session in animals treated with LPS from $E$. coli, we employed a tail-suspension model according to the methodology originally described by Steru et al. (1985) [28]. At different time intervals after LPS treatment $(6,24$ or $48 \mathrm{~h})$, the animals were suspended $50 \mathrm{~cm}$ above the floor by means of an adhesive tape, placed approximately $1 \mathrm{~cm}$ from the tip of the tail. The time during which mice remained immobile was quantified (in s) over a period of $6 \mathrm{~min}$.

\section{Sucrose consumption test}

Anhedonia represents decreased sensation of pleasure, which can be evaluated in mice by measuring reduction of sucrose intake. The protocol used in our study was adapted from the method described by Strakaliva et al, 2004 [29]. For three days, mice received 1\% sucrose solution, and they were subjected to forced swimming, twice a day, for a total of six sessions (temperature water 16 to $19^{\circ} \mathrm{C}$, for $5 \mathrm{~min}$ ), as a pre-stressful stimuli. After the last swimming session, mice were treated with LPS from E. coli $(450 \mu \mathrm{g} / \mathrm{kg}$, i.p), followed by a $24-\mathrm{h}$ period of food and water deprivation, according to the original protocol [29]. Sucrose intake was assessed for $12 \mathrm{~h}$, where mice had free access to two bottles, one with $1 \%$ sucrose solution and another with tap water. The weight differences of bottles were used to calculate the consumption of sucrose with the following formula: $\%$ sucrose intake $=[$ sucrose intake $(g)] \times 100 /[$ sucrose intake $(\mathrm{g})+$ tap water $(\mathrm{g})]$. The animals were treated with the selective kinin $B_{1}$ receptor antagonist SSR240612 (10 mg/kg, p.o., $1 \mathrm{~h})$ or the antidepressant imipramine (10 mg/kg, i.p., $30 \mathrm{~min})$, both administered before LPS injection. Control animals received saline solution, at same schedule of treatment.

\section{Open-field test}

To analyze the effects of swimming session plus LPS treatment on the locomotor activity, the animals were evaluated in an open-field test [30], 6 or $24 \mathrm{~h}$ after endotoxin administration. The experiments were conducted in a sound-attenuated room, under low-intensity light. Mice were individually placed in the centre of an acrylic box $(40 \times 60 \times 50 \mathrm{~cm})$, with the floor divided into 9 squares. The number of squares crossed with the four paws was registered over a period of $6 \mathrm{~min}$.

\section{Body temperature assessment}

Mouse colonic temperature was recorded using a commercially available thermometer (Pro-check ${ }^{\odot}$ ), which was dipped in Vaseline and inserted about $0.5 \mathrm{~cm}$ into a gently hand-restrained mouse. After recording the initial colonic temperature $(t=0)$, the body temperature of mice was evaluated 6 or $24 \mathrm{~h}$ after LPS injection.

\section{Real-time PCR quantification of kinin $B_{1}$ receptor and BDNF mRNA}

Mouse hippocampi and cortex were collected using a special apparatus, after euthanasia by decapitation, at 1 , 3,6 and $24 \mathrm{~h}$ following LPS injection. Total RNA was extracted using Trizol reagent (Invitrogen), according to the manufacturer's instructions. The concentration of total RNA was determined by measuring the absorbance at $260 \mathrm{~nm}$. In order to obtain the reverse transcript (cDNA), $2 \mu \mathrm{g}$ of total RNA were reverse transcribed using oligo $(\mathrm{dT})$ as a primer $(0.05 \mu \mathrm{g}), 50 \mathrm{U}$ of reverse transcriptase (Promega), dNTP (144 $\mu \mathrm{M}$; Promega), reaction buffer $[10 \mathrm{mM}$ dithiothreitol (DTT), $3 \mathrm{mM}$ $\mathrm{MgCl}$, $75 \mathrm{mM} \mathrm{KCl}$, and $50 \mathrm{mM}$ Tris- $\mathrm{HCl}, \mathrm{pH}$ 8.3], and $2 \mathrm{U}$ of RNAsin Plus (Promega), in a final volume of $12.5 \mu$ l. The cDNA was obtained after incubation of the samples for $5 \mathrm{~min}$ at $70^{\circ} \mathrm{C}, 4^{\circ} \mathrm{C}$ for $5 \mathrm{~min}, 37^{\circ} \mathrm{C}$ for $60 \mathrm{~min}, 70^{\circ} \mathrm{C}$ for $5 \mathrm{~min}$, and $4^{\circ} \mathrm{C}$ for $5 \mathrm{~min}$.

$B_{1}$ receptor and BDNF mRNA expression was carried out through fluorescence-based real-time PCR. To this end, approximately $100 \mathrm{ng}$ of cDNA were amplified in duplicates using TaqMan-based chemistry with specific primers and FAM-labeled probes for mouse BDNF (cat\# Mm00432069_m1), B receptor (cat\# Mm00432059_s1) and glyceraldehyde-3-phosphate dehydrogenase (GAPDH; cat\# Mm03302249_g1) as the endogenous control for normalization. Amplifications were carried out in a Thermalcycler (StepOne Plus, Applied Biosystems) for 50 cycles; the fluorescence was collected at each amplification cycle and the data analyzed using the $2^{-\Delta \Delta C t}$ method for relative quantification. Expression of the target genes was calibrated against conditions found in naive animals, i.e., nontreated mice. 


\section{Immunohistochemical studies}

Brain samples were collected 24 h following LPS treatment, and fixed in a phosphate buffered saline (PBS) solution containing $4 \%$ paraformaldehyde for $24 \mathrm{~h}$ at room temperature. Subsequently, the samples were submitted to standard histological proceeding in order to be embedded in paraffin. Hippocampus sections were cut approximately at the level of $3 \mathrm{~mm}$ from bregma $[2,31]$. To determine glial activity, immunohistochemistry was carried out on paraffin tissue sections using CD68 antibody (1:150; Cell Signaling Technology, Beverly, MA, USA). Following quenching of endogenous peroxidase with $1.5 \%$ hydrogen peroxide in methanol for $20 \mathrm{~min}$, high temperature antigen retrieval was performed by immersion of the slides in a water bath at 95 to $98^{\circ} \mathrm{C}$ in $10 \mathrm{mM}$ trisodium citrate buffer $\mathrm{pH}$ 6.0, for $45 \mathrm{~min}$. After overnight incubation at $4^{\circ} \mathrm{C}$ with the primary antibody, the slides were washed with PBS, incubated with the appropriate biotinylated secondary antibody (Dako Cytomation), and then processed using the Streptavidin-HRP reagent (Dako Cytomation), according to the manufacturer's instructions. Sections were developed with DAB (3,3'-diaminobenzidine) (Dako Cytomation) in chromogen solution and counterstained with Harris's hematoxylin. Control and experimental tissues were placed on the same slide and processed under the same conditions.

Images were acquired by Sight DS-5M-L1 digital camera connected to a light microscope Eclipse - 80i (Nikon). Settings for image acquisition were identical for control and experimental tissues. For each mouse, the number of CD-68 positive cells was counted in four different fields of CA1, CA2, CA3 and dentate girus (DG) hippocampal sub regions, using 40X magnification.

\section{Measurement of TNF $\alpha$ levels by ELISA}

The animals were submitted to forced swimming and treated with LPS from E. coli, as described before. Subsequently, they were euthanized by decapitation at distinct intervals of time following LPS $(1,3,6,12$ and $24 \mathrm{~h})$. TNF $\alpha$ levels were determined in serum or in whole brain by means of a standard sandwich ELISA technique, according to the recommendations of the supplier (R\&D Systems, USA). For the brain assays, the tissues were removed and placed in a PBS solution containing 0.05\% Tween 20, $0.1 \mathrm{mM}$ PMSF, $0.1 \mathrm{mM}$ benzamethonium chloride, $10 \mathrm{mM}$ EDTA, $2 \mu \mathrm{g} / \mathrm{ml}$ aprotinin $\mathrm{A}$, and $0.5 \%$ BSA. The mouse brains were homogenized and then centrifuged at $3,000 \times \mathrm{g}$ for $10 \mathrm{~min}$, and the supernatant was employed for ELISA analysis.

\subsection{Preparation of samples for flow cytometry}

Cerebral spinal fluid (CSF) samples were taken from the cisterna magna using a method adapted from Liu and
Duff [32]. Mice were submitted to forced swimming and treated with LPS from E. coli $(450 \mu \mathrm{g} / \mathrm{kg}$, i.p.), as described before. One, three or twenty four h after treatment, mice were anesthetized with a mixture of ketamine (100 mg/kg; i.p.) and xylazine (10 mg/kg; i.p.), and placed on stereotaxic instrument. The head was positioned in a $135^{\circ}$ angle with the body, and a sagittal incision of the skin was made inferior to the occiput. To aspirate the CSF, the metal part of an insulin needle was adapted at one end of a polyethylene 50 tubing, and at the other end a $50 \mu \mathrm{l}$ Hamilton syringe was attached. The needle was attached to the bottom end of the manipulator bar, and $3 \mathrm{~mm}$ of it was inserted into the cisterna magna. The CSF collected was transferred to a $0.5 \mathrm{ml}$ Eppendorf tube, and frozen immediately on dry ice and then kept into $-80^{\circ} \mathrm{C}$ until use. CSF from naïve animals was used as control.

\section{Flow cytometer acquisition and data analysis}

The BD Cytometric Bead Array (CBA) was used to quantitatively measure cytokines in the CSF. The CBA Mouse Inflammation $\mathrm{Kit}^{\oplus}$ (BD Bioscience, San Jose, CA) was used according to the manufacturer's instructions to simultaneously detect interleukin-6 (IL-6), interleukin-10 (IL-10), interferon- $\gamma$ (IFN- $\gamma$ ), tumor necrosis factor alpha (TNF $\alpha)$, and interleukin-12p70 (IL-12p70). Flow cytometer readings were performed using FACSCanto II red laser in a medium range of $633 \mathrm{~nm}$. Data were acquired using FACSDiva software and analyzed using FCAP Array software (all from BD Bioscience). The captured cytokines were detected via direct immunoassay using six different antibodies coupled to phycoerythrin (PE). Standard curves were generated for each cytokine using the mixed cytokine beads standard provided by the kit. The concentration of the standards ranged from 20 to $5000 \mathrm{pg} / \mathrm{ml}$. Five standard curves were plotted such as: cytokine concentration $\mathrm{X}$ mean fluorescence intensity (MFI), using a four-parameter logistic curve fitting model. The concentrations of each CSF cytokine were determined from these four-parameter equations using the MFI value of each cytokine. If a sample had a cytokine concentration below the detection limit for the assay, a value of 0 was assigned for that concentration.

\section{Statistical analysis}

For the behavioral parameters and Elisa protocols, the results are presented as the mean \pm SEM of 6 to 8 animals. For the real-time PCR, flow cytometry and immunohistochemical experiments, the results are given as the mean \pm SEM of 4 independent experiments, performed in triplicate. The statistical comparison between these values was performed by one-way analysis of variance followed by Newman-Keuls post hoc test. P values 
less than $0.05(p<0.05)$ were considered as indicative of significance.

\section{Results \\ General behavioral data}

The results depicted in Figure 1a demonstrate that systemic administration of E. coli LPS $(450 \mu \mathrm{g} / \mathrm{kg}$, i.p.), following a 5 -min forced swimming session, elicited time-related depression-like behavior in mice, according to assessment in the tail-suspension paradigm. The increase of immobility time in animals pre-treated with LPS was statistically significant at $24 \mathrm{~h}(P<0.01)$, but not at $6 \mathrm{~h}(\mathrm{P}>0.05$; results not shown), returning to control levels at $48 \mathrm{~h}(P<0.05)$, in comparison to saline-treated mice. As could be expected, treatment with the classical antidepressant drug imipramine $(10 \mathrm{mg} /$ $\mathrm{kg}$, i.p.), given $30 \mathrm{~min}$ before the behavioral assessment, produced a marked reduction of the immobility time (47 $\pm 16 \%$ of reduction; Figure 1a). Of interest, i.p. treatment with the selective $B_{1}$ receptor antagonists $\mathrm{R}-715(0.5 \mathrm{mg} / \mathrm{kg}, 30 \mathrm{~min})$ or SSR240612 $(5 \mathrm{mg} / \mathrm{kg}$, i.p., $30 \mathrm{~min}$ ), or even oral administration of SSR240612 $(10 \mathrm{mg} / \mathrm{kg}, 1 \mathrm{~h})$, caused a significant inhibition of depression-like behavior induced by LPS (Figure 1c). The percentages of inhibition for animals treated with $B_{1}$ receptor antagonists were: $46 \pm 6 \%, 33 \pm 7 \%$ and $30 \pm 6 \%$, respectively. On the other hand, the selective kinin $B_{2}$ receptor antagonist FR173657 (30 mg/kg, i.p., $30 \mathrm{~min}$ ) failed to significantly alter the immobility time in our model $(P>0.05$; Figure 1b). Injection of LPS after three days of forced swimming in Swiss mice led to a significant decrease of sucrose consumption $(P<$ $0.05)$. The decreased sucrose intake was notably prevented by pre-treating animals with the antidepressant imipramine $(10 \mathrm{mg} / \mathrm{kg}$, i.p., $30 \mathrm{~min})$ or with the $B_{1}$ receptor antagonist SSR240612 (10 mg/kg, p.o, $1 \mathrm{~h})$ $(P>0.05$; Figure $1 \mathrm{~d})$.

It is well known that LPS treatment evokes some classical CNS-associated changes in rodents [3-5]. Confirming literature data, our results demonstrate that $E$. coli LPS administration in mice previously submitted to forced swimming, is able to cause a marked reduction of body temperature (Figure 1e), and of locomotor activity when assessed in the open-field arena. The locomotor activity was significantly reduced at $6 \mathrm{~h}$ after LPS $(P<0.05)$, returning to the control levels at $24 \mathrm{~h}$ (Figure 1f). Body temperature was found significantly reduced at $6 \mathrm{~h}(P<0.01)$, but not at $24 \mathrm{~h}$ after LPS $(P>0.05)$. Remarkably, the administration of R-715 (0.5 mg/kg, i.p.), $30 \mathrm{~min}$ before the test, did not display any significant effect on this parameter as assessed at $6 \mathrm{~h}$ (Figure 1e). Considering the oral bioavailability of SSR240612, the next experiments were carried out using only this antagonist.

\section{Biochemical and molecular approaches}

We wondered whether the effects of selective kinin $B_{1}$ receptor antagonists might be related to changes of $B_{1}$ receptor expression in CNS structures. Therefore, $B_{1}$ receptor mRNA expression was measured in the hippocampus and frontal cortex of mice submitted to a session of forced swimming, followed by LPS administration $(450 \mu \mathrm{g} / \mathrm{kg}$, i.p.). Quantitative real-time experiments revealed a time-dependent, marked increase in $B_{1}$ receptor mRNA levels in hippocampus, which peaked at $1 \mathrm{~h}$ (about 2.5-fold increase) (Figure 2a) while in the cortex this increase was almost 40 fold $1 \mathrm{~h}$ after LPS treatment (Figure 2b).

As observed in Figure 3, forced swimming followed by LPS treatment produced a marked increase in CD68 immunoreactivity in mouse hippocampus, indicative of increased glial cell activation. Of relevance, CD68 labeling was almost completely inhibited in animals pre-treated with the selective kinin $B_{1}$ receptor antagonist SSR240612 (5 mg/kg, i.p.), but not by the antidepressant drug imipramine (10 mg/kg, i.p.), both given $30 \mathrm{~min}$ before LPS. These findings suggest that different mechanisms appear to mediate imipramine and kinin $B_{1}$ receptor antagonist antidepressant-like effects. It has been described that depression is associated with decreased expression of neurotrophic factors, such as BDNF [33-35]. In our study, real-time PCR experiments revealed a marked decrease in BDNF expression in hippocampus of mice submitted to our protocol of depression, when assessed at both the 6- and the 24-h timepoints (an approximate $50 \%$ reduction). However, this parameter was not significantly affected by pre-treating animals with the kinin $B_{1}$ receptor antagonist SSR240612 (5 mg/kg, i.p., $30 \mathrm{~min}$ ) (Figure 4).

Next, in order to correlate the changes elicited by LPS with cytokine production, we assessed levels of TNF $\alpha$ in whole brain or mouse serum. The animals were submitted to a forced swimming session and treated with E. coli LPS, as described above. This series of results showed the occurrence of a marked, time-dependent increase in TNF $\alpha$ production, either in brain or in serum of LPStreated mice. In serum, TNF $\alpha$ levels peaked between 1 and $3 \mathrm{~h}$ (an approximate 90-fold increase), returning to basal levels $6 \mathrm{~h}$ following LPS administration (Figure 5a). The increase of TNFa in the brain was maximal between 3 and $6 \mathrm{~h}$ after LPS (about 1.8-fold augmentation), being reduced to control values after $12 \mathrm{~h}$ (Figure $5 \mathrm{~b}$ ). We also analyzed cytokine content in CSF from LPS-treated mice, using flow cytometry analysis. The cytokines IL-6, IL-10, IFN- $\gamma$ were below detection levels, while the concentration of IL-12 was similar to that observed in naïve animals (data not shown). Of interest, CSF TNF $\alpha$ levels peaked $1 \mathrm{~h}$ after LPS injection and remained elevated until $3 \mathrm{~h}$ later (about 340 and 90-fold increase, respectively) (Figure 5c). 


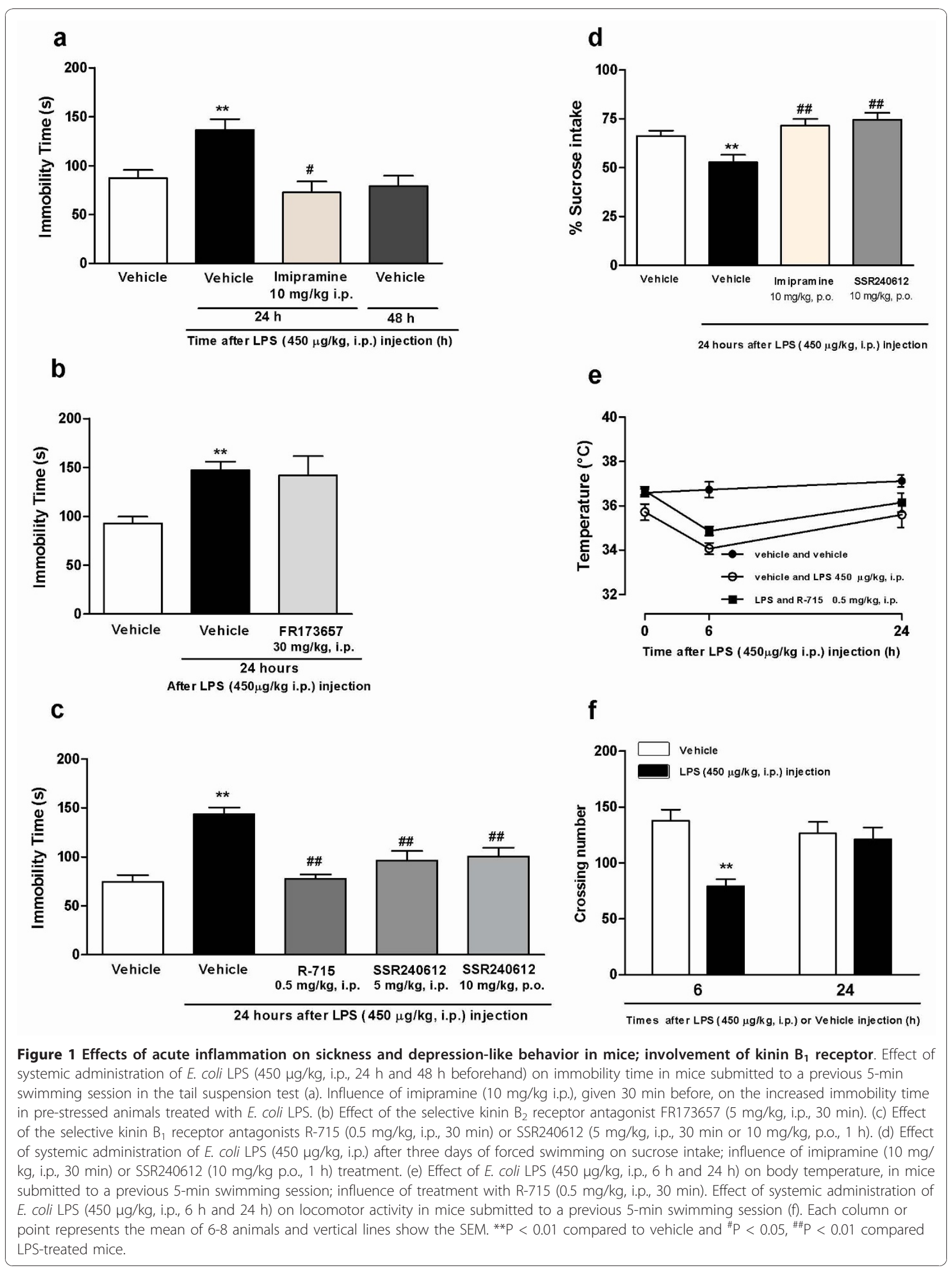


a

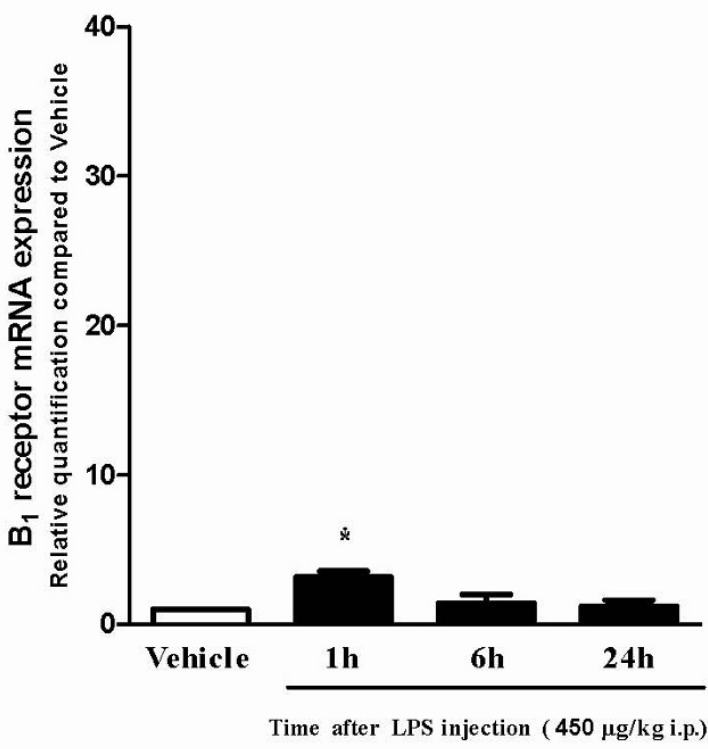

b

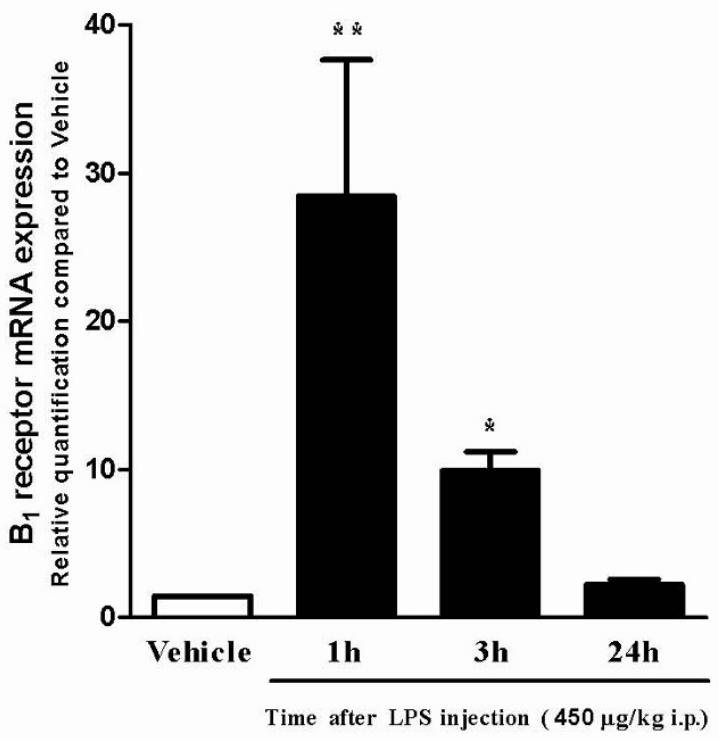

Figure 2 Expression of $B_{1}$ receptor mRNA in hippocampus and cortex of mice after acute inflammation. Time-related effects of a 5-min forced swimming session plus E. coli LPS treatment $(450 \mu \mathrm{g} /$ kg, i.p.) on $B_{1}$ receptor mRNA expression in the hippocampus (a) and cortex (b) of mice. Each column represents the mean of 4 animals and vertical lines show the SEM. ${ }^{*} P<0.05$ and ${ }^{* *} P<0.01$ compared to vehicle-treated mice.

Since previous literature data have shown a close interrelation between $\mathrm{TNF} \alpha$ and $\mathrm{B}_{1}$ receptor upregulation $[10,14]$, we further investigated the role played by TNF $\alpha$ in the depression-like behavior observed in our experimental paradigm. For that purpose, we employed
TNF $\alpha$ p55 receptor-deficient mice. As TNF $\alpha$ p55 receptor knockout animals used in the present study are C57/ BL6 inbred, we employed this mouse strain in this part of the study. In C57/BL6 mice, a dose of $1000 \mu \mathrm{g} / \mathrm{kg}$ of E. coli LPS was necessary to evoke a significant increase in immobility time in the tail-suspension test, comparable to that obtained with a $450 \mu \mathrm{g} / \mathrm{kg}$ dose in CF1 mice (about 1.5-fold in relation to saline-treated animals). Strikingly, the depression-like behavior caused by forced swimming plus LPS treatment $(1000 \mu \mathrm{g} / \mathrm{kg}$, i.p.) was virtually abolished in mice with genetic deletion of TNF $\alpha$ p55 receptors (Figure $5 \mathrm{~d}$ ). Of note, the increase of $\mathrm{B}_{1}$ receptor mRNA expression in mice submitted to forced swimming plus LPS treatment was completely absent in TNF $\alpha$ p55 receptor knockout animals (Figure 5e).

\section{Discussion}

During the last few years, several advances have been achieved in our understanding of the genetic, biochemical and immunological changes implicated in depression [35]. Concerning the immunological mechanisms, certain pro-inflammatory cytokines, mainly IL-6, IL-1 $\beta$ and TNF $\alpha$, have been recently pointed out as pivotal molecules for depression-related behaviors following infection. These cytokines are likely able to coordinate local and systemic inflammatory responses to pathogens $[2,22]$. In the depression-like behavioral paradigm employed herein, we demonstrate that administration of LPS (450 $\mu \mathrm{g} / \mathrm{kg}$, i.p.) in mice previously submitted to a 5 -min swimming session, produces earlier signals of sickness behavior, such as decreased body temperature and locomotor activity $6 \mathrm{~h}$ post-LPS, which are followed by a later manifestation of depression-like behavior, i.e. an increase of immobility time in the tail suspension test, $24 \mathrm{~h}$ post-LPS. This is in line with literature data indicating that sickness behavior represents a normal initial response to infectious stimuli $[33,36]$, although depression-like states might persist after initial sickness alterations have resolved [3,37].

To the best of our knowledge, there is no previous study correlating kinin $\mathrm{B}_{1}$ receptors and depression. These receptors are commonly absent under normal conditions in the periphery, but might be rapidly up-regulated by stressful stimuli. Interestingly, basal expression of $\mathrm{B}_{1}$ receptor has been described in spinal cord and some brain structures, such as cerebral cortex, hippocampus, thalamus, hypothalamus, amygdala, and choroid plexus epithelial cells $[10,38,39]$. Even though the exact role of kinins in the brain is not clear, basal expression of $B_{1}$ receptor in the nervous system is compellingly suggestive of a central role for these molecules $[10,19,40]$. Herein, we have assessed whether $B_{1}$ receptors might be implicated in the depression-like behavior induced by LPS and pre-stressful stimuli. 
a

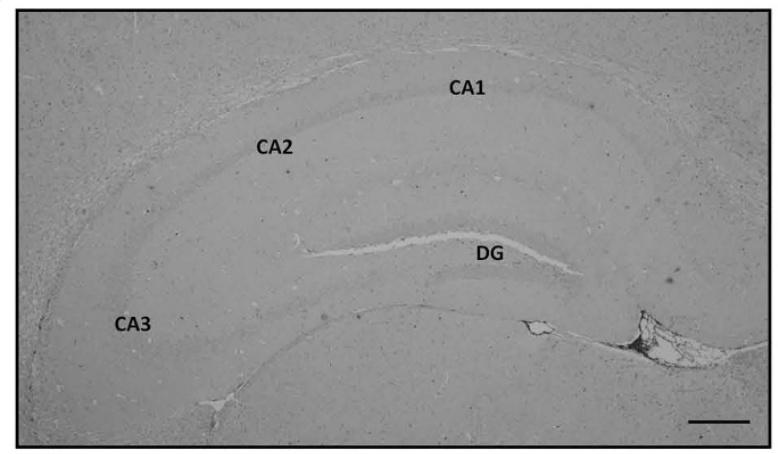

C

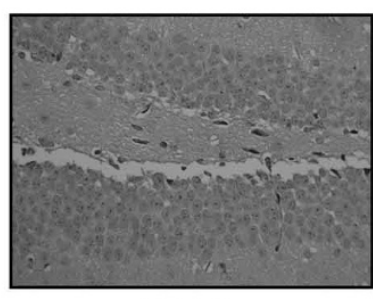

Vehicle

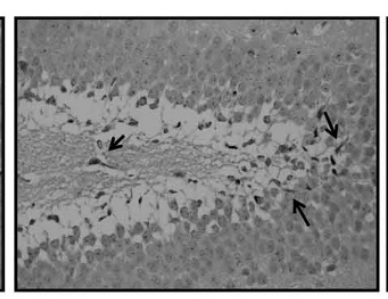

Vehicle

b

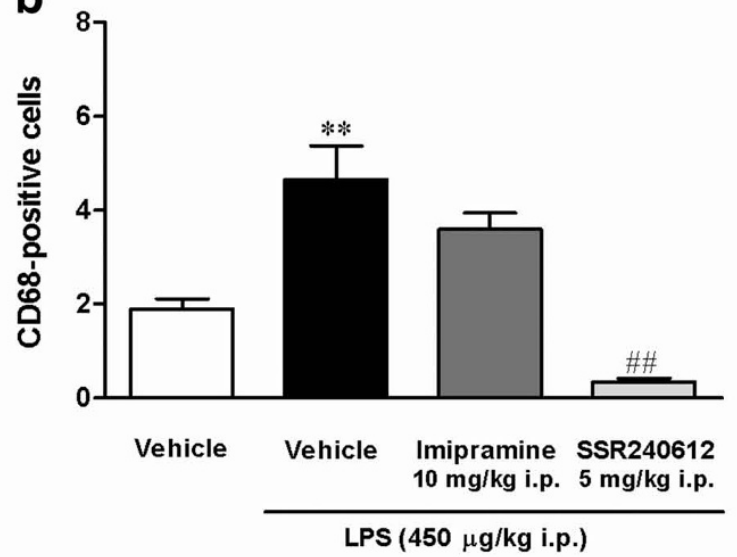

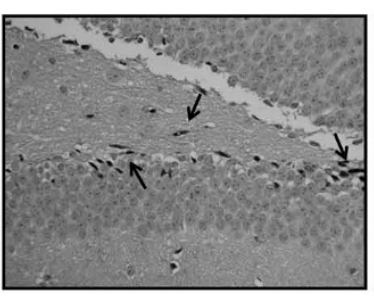

Imipramine

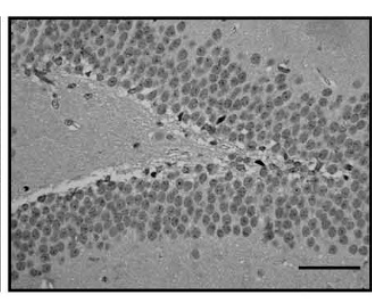

SSR240612

\section{LPS $(450 \mu \mathrm{g} / \mathrm{kg}$ i.p.)}

Figure 3 Microglial activation in the mouse hippocampus following acute inflammation; effect of $B_{1}$ receptor antagonism. Effect of systemic administration of E. coli LPS (450 $\mathrm{\mu g} / \mathrm{kg}$, i.p., 24 h) on microglial activation (CD68-positivity) in the hippocampus of mice submitted to a previous 5-min forced swimming session. Mice were treated with imipramine (10 mg/kg i.p.) or SSR240612 (5 mg/kg, i.p.), given $30 \mathrm{~min}$ beforehand. (a) Representative image of CA1, CA2, CA3 and dentate gyrus (DG) subregions of hippocampus (Scale bar = $200 \mu \mathrm{m}$, original magnification, $\times 40$ ). (b) Graphic representation on the average number of CD68-positive cells per field, determined in the CA1, CA2, CA3, and DG subregions of the hippocampus. (c) Representative images of CD68 immunohistochemistry in the DG subregion of hippocampus (Scale bar $=50 \mu \mathrm{m}$, original magnification, $\times$ 400) from pre-stressed animals treated with E. coli LPS, following imipramine (10 mg/kg i.p.), SSR240612 (5 mg/kg, i.p., $30 \mathrm{~min}$ or $10 \mathrm{mg} / \mathrm{kg}$, p.o., 1 h), or saline $30 \mathrm{~min}$ before. LPS treatment showed an increase in the number of CD68-positive cells (c, arrows) in the hipocamppus, and SSR240612 (5 mg/kg, i.p., $30 \mathrm{~min}$ or $10 \mathrm{mg} / \mathrm{kg}$, p.o., 1 h), was able to reduce this increase (c). Each column represents the mean of 4 animals and the vertical lines show the SEM. ${ }^{* P}<0.05$, ${ }^{*} \mathrm{P}<0.01$ and ${ }^{* * *}<0.001$ compared to vehicle-treated mice.

The depression-like state observed in the tail suspension test was significantly reduced by the antidepressant imipramine, in a dose which was effective in stressed rodents [27]. Interestingly, the increased immobility was significantly inhibited by treatment with either selective $\mathrm{B}_{1}$ receptor antagonists $\mathrm{R}-715$ or SSR240612. These results are indicative of a relevant role for $B_{1}$ receptors in depression-like behavior. Our in vivo data were reinforced by real-time PCR experiments, which demonstrated a marked increase in $B_{1}$ receptor mRNA expression in hippocampus, and notably, in the cortex of mice submitted to forced swimming plus LPS administration. Alterations of hippocampal plasticity have been widely demonstrated in depression associated with stressful insults [32,40-42]. Nevertheless, the present study is, to the best of our knowledge, the first demonstration that infection associated with a stressful stimulus might up-regulate $B_{1}$ receptors in the CNS, leading to depressive behavior. Conversely, treatment of mice with the selective $B_{2}$ receptor antagonist FR173657 failed to significantly affect immobility time in our depression paradigm. This is well aligned with the proposed physiological roles of kinin $B_{2}$ receptors [43]. Considering this paradigm, the participation of $\mathrm{B}_{2}$ receptors was not further considered in the present study.

Of high interest, functional data obtained in the tail suspension test was extended by results employing the anhedonia paradigm of sucrose intake, in which SSR240612 was able to completely reverse reduced sucrose consumption in LPS-treated mice. It is well known that depression is likely associated with anhedonia states, where pleasure sensations are reduced or even missing $[29,44]$. It is noteworthy that stressful forced swimming plus LPS administration resulted in a 


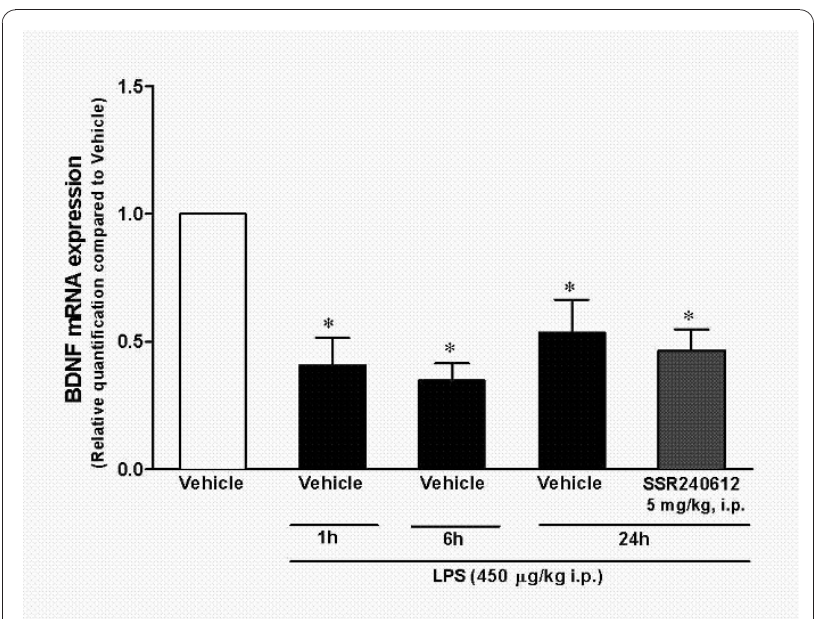

Figure 4 BDNF mRNA expression in hippocampus and cortex of mice after acute inflammation; effects of $B_{1}$ receptor antagonism. Effect of systemic administration of E. coli LPS (450 $\mu \mathrm{g} / \mathrm{kg}$, i.p., $6 \mathrm{~h}$ and $24 \mathrm{~h}$ ) on BDNF mRNA expression in the hippocampus of mice submitted to a previous 5-min forced swimming session, according to assessment by real-time PCR. Influence of treatment with SSR240612 (5 mg/kg, i.p.), given $30 \mathrm{~min}$ beforehand. Each column represents the mean of 4 animals and vertical lines show the SEM. ${ }^{*} P<0.05$ compared to vehicle-treated mice.

significant decrease in sucrose consumption in Swiss mice, a parameter that was reversed by the antidepressant imipramine, which reinforces the validity of our experimental design [45]. On the other hand, sickness behavior-induced hypothermia was not significantly altered by the administration of the $B_{1}$ receptor antagonist R-715. This evidence indicates that blocking $B_{1}$ receptors is able to reverse later depression-like symptoms without interfering with early sickness behavior, which seems to be coordinated mainly by cytokines [46].

The major immunocompetent components of the CNS are represented by microglia and astrocytes, and the activation of these cells likely contributes to the pathogenesis of depression $[43,47,48]$. Our data clearly demonstrate that forced swimming followed by LPS treatment results in activation of microglia in mice, as indicated by an enhancement of CD-68 immunostaining in hippocampus $24 \mathrm{~h}$ after LPS injection, when $B_{1}$ mRNA levels return to basal. It has been demonstrated that microglial activation in response to several kinds of injury drives the release of neurotoxic mediators, such as pro-inflammatory cytokines $[3,49]$. Of relevance, systemic treatment with the selective non-peptide $B_{1}$ receptor antagonist SSR240612 virtually abolished the CD-68 immunopositivity, but notably this parameter was not significantly altered by imipramine. This allows us to suggest that antidepressant-like effects of $B_{1}$ receptor antagonists, but not that caused by imipramine, are related to inhibition of microglial activation. These findings are quite relevant and open a new avenue to understand depressive states, especially those associated to infection.

Depression is clearly associated with synaptic plasticity changes, resulting in decreased BDNF function, among other biochemical alterations. It has been demonstrated that under stressful conditions, the BDNF gene is repressed leading to neuronal apoptosis in hippocampus $[40,50]$. Of interest, BDNF infusion in some brain regions induces antidepressant-like effects in animal models [50-52]. Additionally, most monoaminergic antidepressant drugs are known to restore normal BDNF transcriptional levels [33-35,34]. Our depression model caused a sustained reduction in BDNF mRNA expression in hippocampus (up to $24 \mathrm{~h}$ ). Of note, BDNF mRNA expression was not significantly altered by previous administration of the selective $B_{1}$ receptor antagonist SSR240612. Therefore, although $B_{1}$ receptor antagonism prevented microglial activation, it failed to restore decreased brain levels of BDNF. These results suggest that SSR240612 seems to have an antidepressant-like activity by acting through different mechanisms from usual antidepressants; acting preferentially by an inflammatory pathway, and not by interfering with BDNF.

As mentioned above, pro-inflammatory cytokines are deeply involved in the pathogenesis of depression [53,54]. Of note, patients with major depressive disorder have increased expression of soluble TNF $\alpha$ receptors $[55,56]$, and patients under treatment with TNFa antagonists display a general improvement of depressive symptoms and life quality $[57,58]$. Herein, we reinforce this hypothesis by demonstrating that LPS administration in pre-stressed mice results in a marked increase of TNF $\alpha$ levels in serum, CSF and whole brain. TNF $\alpha$ production was initially augmented in serum (between 1 and $3 \mathrm{~h}$ ), and later increased in whole brain (between 3 and $6 \mathrm{~h}$ ). Therefore, it is possible to argue that increased TNF $\alpha$ levels in serum are the main factor responsible for sickness behavioral changes (i.e. hypothermia and reduced locomotor activity), whereas the elevation of this cytokine in brain underlies the depression-like behavior in the tail suspension test. In addition, multiplex cytokine analysis demonstrated a marked increase of TNFa levels in CSF obtained from LPS-treated mice (between 1 and $3 \mathrm{~h}$ ), although the levels of other cytokines remained unaltered. The presence of TNF $\alpha$ in the CSF supports the idea of a communication pathway between the brain and the immune system. When toll-like receptors on macrophage-like cells residing in the circumventricular receptors are activated, they respond by producing proinflammatory cytokines, such as TNF $\alpha$ [3]. As the circumventricular organs lie outside the blood-brain barrier ( $\mathrm{BBB})$, and the $\mathrm{BBB}$ is relatively impermeable to 


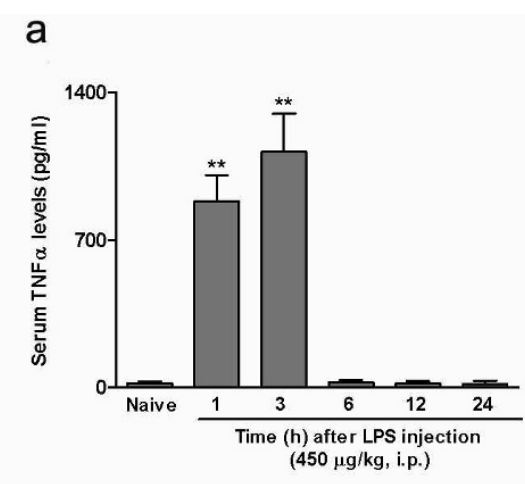

$$
\text { b }
$$

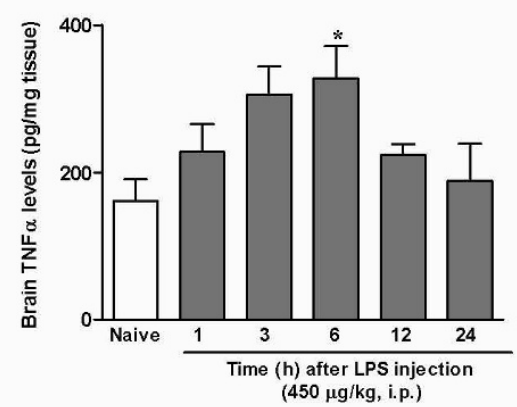

C

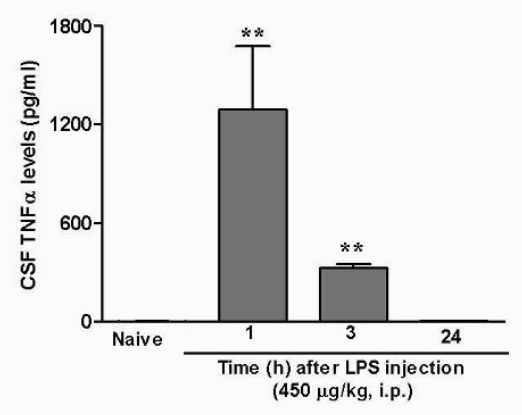

d

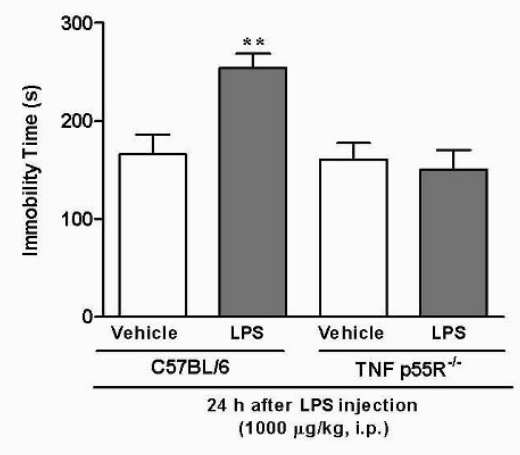

e

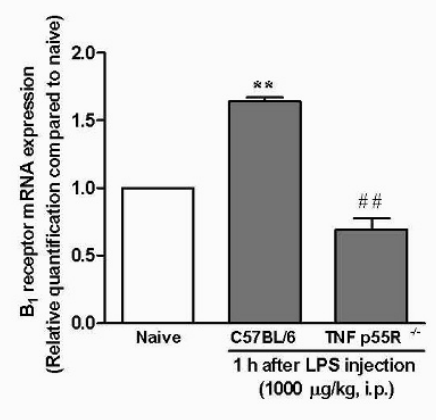

Figure 5 TNF $\alpha$ levels in serum and brain of mice following acute inflammation; relevance of TNF $\alpha$ p55 receptor for $B_{1}$ receptor mRNA expression. Time-related effects of treatment with LPS (450 $\mu \mathrm{g} / \mathrm{kg}$, i.p.) on TNF $\alpha$ levels in serum (a), whole brain (b) or CSF (c) of CF1 mice, submitted to a previous 5-min forced swimming session, according to assessment by ELISA sandwich (a, b) or CBA (c) assays. (d) Effect of systemic administration of E. coli LPS (1000 $\mu \mathrm{g} / \mathrm{kg}$ i.p., 24 h) on immobility time, in C57/BL6 or TNF $\alpha$ p55 receptor knockout mice, as assessed in the tail suspension test. (e) Evaluation of $B_{1}$ receptor mRNA expression in C57/BL6 or TNF $\alpha$ p55 receptor knockout mice that had been previously submitted to a 5-min swimming section, and were pre-treated with E. coli LPS (1000 $\mu \mathrm{g} / \mathrm{kg}$ i.p., 1 h). Each column represents the mean of 6-8 animals and vertical line show the SEM. ${ }^{*} \mathrm{P}<0.05,{ }^{*} \mathrm{P}<0.01$ compared to naive or vehicle-treated mice and ${ }^{\# \#} \mathrm{P}<0.01$ compared to $\mathrm{C} 57 \mathrm{BL} / 6$ mice.

cytokines, the mechanisms by which circulating cytokines might influence the brain function remain a matter of debate [34]. One established theory is that they can enter the brain by volume diffusion $[3,58,58]$. Cytokines might additionally gain access to the brain through sites where BBB is somewhat compromised, e.g. by stressful events or immunologic challenges, such as those used in our protocol [34]. Besides, kinins enhance permeability of $\mathrm{BBB}$. This would disturb BBB functioning, leading to various neuropathological conditions related to cytokine entrance into the brain, including depression $[59,60]$.

To gain further insights into the relevance of TNF $\alpha$ in our experimental paradigm, we employed TNF $\alpha$ p55 receptor-KO mice. Both depression-like behavior and upregulation of $B_{1}$ receptors induced by forced swimming plus LPS treatment were virtually abolished in TNF $\alpha$ p55 receptor-KO mice. The relevance of TNF $\alpha$ for the up-regulation of $\mathrm{B}_{1}$ receptors has been described before by our group [14-17]. The experimental evidence provided herein clearly suggests a link between the cytokine TNF $\alpha$ and the kinin $B_{1}$ receptor upregulation in depression genesis. The present data provide good evidence suggesting that generation of this pro-inflammatory cytokine seems to exert a critical role for LPS to induce $B_{1}$ receptor upregulation, as already demonstrated [14].

Most experts agree that depression should be viewed as a syndrome, not a disease [60]. The current hypothesis linking depression and the immune system suggests that cytokines and other immune mediators work as "sensor" molecules, capable of transforming noncognitive stimuli (i.e. inflammatory process) into cognitive stimuli, allowing the CNS to recognize them, and to elaborate an integrated response to the peripheral event. Therefore, molecules released during peripheral inflammatory events may influence central factors controlling homeostasis and behavior $[58,59]$. Our findings bring a new 
piece of evidence into the depression disorder puzzle which may help to understand its etiology: kinin $B_{1}$ receptors might exert a critical role in affective disorders, such as depression. The participation of $\mathrm{B}_{1}$ receptors in depressive alterations seems to be related to microglial activation, an event that seems to be associated with the subsequent production of TNF $\alpha$ in the brain. It is tempting to suggest that a clinical trial with orally available selective $B_{1}$ receptor antagonists should be performed to evaluate whether or not these molecules could help treating clinical symptoms of depression.

\section{Abbreviations}

BBB: blood-brain barrier; CBA: Cytometric Bead Array; DAB: 3,3'diaminobenzidine; DG: dentate girus; HPA: hypothalamus-pituitary-adrenal; IFN- $\gamma$ : interferon- $\gamma$; IL-10: interleukin-10; IL-12p70: interleukin-12p70; IL-6: interleukin-6; KO: knockout; LPS: lipopolysaccharide; PBS: phosphate buffered saline; PE: phycoerythrin; MFI: mean fluorescence intensity; TLR: Toll-Like Receptors; TNFa: tumor necrosis factor alpha.

\section{Acknowledgements}

This work was supported by grants from the Conselho Nacional de Desenvolvimento Científico e Tecnológico (CNPq), the Coordenação de Aperfeiçoamento de Pessoal de Nível Superior (CAPES), and the Fundação de Apoio à Pesquisa do Estado de Santa Catarina (FAPESC). I.S.M. is an undergraduate Pharmacy Student receiving a Grant from Fundação de Apoio à Pesquisa do Estado do Rio Grande do Sul (FAPERGS). F.N.D. is a PhD Pharmacology Student supported by Grants from CNPq; A.F.V and J.M.S holds a Post-doctoral Fellowship from CNPq.

\section{Author details}

'Pharmacology Department, Universidade Federal de Santa Catarina, Florianópolis, SC, Brazil. 'Faculty of Pharmacy, Pontifícia Universidade Católica do Rio Grande do Sul, Porto Alegre, RS, Brazil. ${ }^{3}$ Faculty of Dentistry, Pontifícia Universidade Católica do Rio Grande do Sul, Porto Alegre, RS, Brazil. ${ }^{4}$ Institute of Toxicology, Pontifícia Universidade Católica do Rio Grande do Sul, Porto Alegre, RS, Brazil.

\section{Authors' contributions}

AFV; ISM; FND; CPF; JMS and MMC performed the experiments and analyzed the data. MMC and JBC participated in design and coordination, provided useful advice, wrote and reviewed the manuscript. All authors read and approved the final manuscript.

\section{Competing interests}

The authors declare that they have no competing interests.

Received: 25 October 2010 Accepted: 31 December 2010 Published: 31 December 2010

\section{References}

1. Olesen J, Lekander I, Sobocki P: Resource Allocation to brain research in Denmark: an exemple for other European countries. Eur J Neurol 2007, 14:667-671.

2. Maes M: Evidence for an immune response in major depression: a review and hypothesis. Prog Neuro-Psychopharmacol \& Biol Psychiat 1995, 19:11-38.

3. Dantzer R, O'Connor JC, Johnson RW, Kelly KW: From inflammation to sickness and depression: when the immune system subjugates the brain. Nat Rev Neurosci 2008, 9:46-56.

4. Godbout JP, Moreau M, Lestage J, Chen J, Sparkman NL, O'Connor J, Castanon N, Kelley KW, Dantzer R, Johnson RW: Aging exacerbates depressive-like behavior in mice in response to activation of the peripheral innate immune system. Neuropsychopharmacology 2008, 33:2341-2351.
5. Moreau M, André C, O'Connor JC, Dumich SA, Woods JA, Kelly KW, Dantzer R: Inoculation of Bacillus Calmette-Guérin to mice indices an acute episode of sickness behavior followed by chronic depressive-live behavior. Brain Behav Immun 2008, 22:1087-1095.

6. Hübschle T, Mütze J, Mühlradt PF, Korte S, Gerstberger R, Roth J: Pyrexia, anorexia, adipsia and depressed motor activity in rats during systemic inflammation induced by the Toll-like receptors- 2 and -6 agonists MALP2 and FSL-1. Am J Physiol Regul Comp Physiol 2006, 290:180-187.

7. Hayashi T, Cottam HB, Chan M, Jin G, Tawatao Rl, Crain B, Ronacher L, Messer K, Carson DA, Corr M: Mast cell-dependent anorexia and hypothermia induced by mucosal activation of Toll-like receptor 7. Am J Physiol Regul Integr Comp Physiol 2008, 295:R123-R132.

8. Wang $\mathrm{H}$, Ehnert C, Brenner GJ, Woolf $\mathrm{CJ}$ : Bradykinin and peripheral sensitization. Biol Chem 2006, 387:11-14.

9. Calixto JB, Medeiros R, Elizabeth SF, Ferreira J, Cabrini DA, Campos MM: Kinin B1 receptors: Key G-protein-coupled receptors and their role in inflammatory and painful processes. Br J Pharmacol 2004, 143:803-818.

10. Leeb-Lundberg LM, Marceau F, Müller-Esterl W, Pettibone DJ, Zuraw BL: International union of pharmacology. XLV. Classification of the kinin receptor family: from molecular mechanisms to pathophysiological consequences. Pharmacol Rev 2005, 57:27-77.

11. Campos MM, Leal PC, Yunes RA, Calixto JB: Non-peptide antagonists for kinin $B 1$ receptors: new insights into their therapeutic potential for the management of inflammation and pain. Trends Pharmacol Sci 2006, 27:646-651.

12. Duchene J, Ahluwalia A: The kinin B(1) receptor and inflammation: new therapeutic target for cardiovascular disease. Curr Opin Pharmacol 2009, 9:125-131.

13. Passos GF, Fernandes ES, Campos MM, Araújo JG, Pesquero JL, Souza GE, Avellar MC, Teixeira MM, Calixto JB: Kinin B1 receptor up-regulation after lipopolysaccharide administration: role of proinflammatory cytokines and neurotrophil influx. J Immunol 2004, 172:1837-1847.

14. Dornelles FN, Santos DS, Van Dyke TE, Calixto JB, Batista EL Jr, Campos MM: In vivo up-regulation of kinin $B 1$ receptors after treatment with Porphyromonas gingivalis lipopolysaccharide in rat paw. J Pharmacol Exp The 2009, 330:756-763.

15. Campos MM, Souza GE, Calixto JB: Modulation of kinin B1 but not B2 receptors-mediated rat paw edema by IL-1 beta and TNFalpha. Peptides 1998, 19:1269-1276.

16. Rocha AC, Fernandes ES, Quintão NL, Campos MM, Calixto JB: Relevance of tumour necrosis factor-alpha for the inflammatory and nociceptive responses evoked by carrageenan in the mouse paw. Br J Pharmacol 2006, 148:688-695

17. Bascands JL, Bachvarova M, Neau E, Schantra JP, Bachvarov D: Molecular determinants of LPS-induced acute inflammation: Implication of the kinin B1 receptor. Biochem Biophys Res Commun 2009, 386:407-412.

18. Quintão NL, Passos GF, Medeiros R, Paszcuk AF, Pesqueiro JB, Campos MM, Calixto JB: Neuropathic pain-like behavior after brachial plexus avulsion in mice: the relevance of kinin B1 and B2 receptors. J Neurosci 2008, 28:2856-2863.

19. Ongali B, Hellal F, Plotkine M, Marchand-Verrecchia C, Pruneau D, Couture R: Autoradiographic analysis of mause brain $\mathrm{B} 1$ and $\mathrm{B} 2$ receptors after closed head trauma and ability of Anatibant mesylate to cross the blood-brain barrier. J Neurotrauma 2006, 23:696-707.

20. Prediger RDS, Medeiros R, Pandolfo P, Duarte FS, Passos GF, Pesqueiro JB, Campos MM, Calixto JB, Takahashi RN: Genetic deletion or antagonism of kinin $B 1$ and $B 2$ receptors improves cognitive déficits in a mouse model of alzheimer's disease. Neurosci 2008, 151:631-643.

21. Hart BL: Biological basis of the behavior of sick animals. Neurosci Biobehav Rev 1988, 12:123-137.

22. Robinson MJ, Edwards SE, lyengar S, Bymaster F, Clark M, Katon W: Depression and pain. Front Biosci 2009, 14:5031-5051.

23. Zimmermann $\mathrm{M}$ : Ethical guidelines for investigations of experimental pain in conscious animals. Pain 1983, 16:109-110.

24. Ueno A, Naraba H, Kojima F, Morita E, Oh-ishi S: FR190997, a novel bradykinin B2 agonist, expresses longer action than bradykinin in paw edema formation and hypotensive response. Immunopharmacology 1999, 45:89-93.

25. Costa R, Fernandes ES, Menezes-de-Lima O Jr, Campos MM, Calixto JB: Effect of novel selective non-peptide kinin $B(1)$ receptor antagonists on mouse pleurisy induced by carrageenan. Peptides 2006, 27:2967-2975. 
26. Viana A, Rates S, Naudin B, Janin F, Costentin J, do Rego JC: Effects of acute or 3-day treatments of Hypericum caprifoliatum Cham. \& Schltdt. (Guttiferae) extract or of two established antidepressants on basal and stress-induced increase in serum and brain corticosterone levels. J Psychopharmacol 2008, 22:681-690.

27. Steru L, Chermat R, Thierry B, Simon P: The tail suspension test: a new method for screening antidepressants in mice. Psychopharmacology 1985, 85:367-70.

28. Strekalova T, Spanagel R, Bartsch D, Henn AF, Gass P: Stress-induced anhedonia in mice is associated with deficits in Forced Swimming and Exploration. Neuropsychophamacology 2004, 29:2007-2017.

29. Campos MM, Ongali B, De Souza Bruck H, Schanstra JP, Girolami JP, Chabot JG, Couture R: Expression and distribution of kinin B1 receptor in the rat brain and alterations induced by diabetes in the model of streptozotocin. Synapse 2005, 57:29-37.

30. Paxinos $G$, Watson $C$ : The rat brain in stereotaxic coordinates. Academic Press, Inc. New York: Academic Press Limited, 4 1998:1:1-25.

31. Liu L, Duff K: A technique for serial colletion of celebraspinal fluid from the cisterna magna in mouse. J Vis Exp 2008, 10:960.

32. Duman $\mathrm{R}$, Heninger GR, Nestler EJ: A molecular and cellular theory of depression. Arch Gen Psy 1997, 54:597-606.

33. Anisman $\mathrm{H}$, Merali Z, Hayley S: Neurotransmitter, peptide and cytokine processes in relation to depressive disorder: comorbidity between depression and neurodegenerative disorders. Prog Neurobiol 2008, 85:1-74.

34. Maes M, Yirmyia R, Noraberg J, Brene S, Hibbeln J, Perini G, Kubera M, Bob P, Lerer B, Maj M: The inflammatory \& neurodegenerative (I\&ND) hypothesis of depression: leads for future research and new developments in depression. Metab Brain Dis 2009, 24:27-53.

35. Gibb J, Audet MC, Hayley S, Anisman H: Neurochemical and behavioral responses to inflammatory immune stressors. Front Biosci 2009, 1:275-295.

36. O'Connor JC, André C, Wang Y, Lawson MA, Szegedi SS, Lestage J, Castanon N, Kelley KW, Dantzer R: Interferon-gamma and tumor necrosis factor-alpha mediate the upregulation of indoleamine 2,3-dioxygenase and the induction of depression-like behavior in mice in response to bacillus Calmette-Guerin. J Neurosci 2009, 29:4200-4209.

37. Mahabeer R, Bhoola KD: Kallikrein and kinin receptor genes. Pharmacol Ther 2000, 88:77-89.

38. Shughrue PJ, KY B, Austin CP: Localization of B1 bradykinin receptor mRNA in the primate brain and spinal cord: an in situ hybridization study. J Comp Neurol 2003, 465:372-384

39. Talbot S, Théberge-Turmel P, Liazoghli D, Sénécal J, Gaudreau P, Couture R: Cellular localization of kinin B1 receptor in the spinal cord of streptozotocin-diabetic rats with a fluorescent [Balpha-bodipy]des-Arg9bradykinin. Neuroinflammation 2009, 6:11.

40. Sapolsky RM: The possibility of neurotoxicity in the hippocampus in major depression: a primer on neuron death. Biol Psychiatry 2000 48:755-765.

41. Seguin JA, Brennan J, Mangano E, Havlev S: Proinflammatory cytokines differentially influence adult hippocampal cell proliferation depending upon the route and chronicity of administration. Neuropsychiatr Dis Treat 2009, 5:5-14.

42. Calixto JB, Cabrini DA, Ferreira J, Campos MM: Inflammatory pain: kinins and antagonists. Curr Opin Anaesthesiol 2001, 14:519-526.

43. Gorwood P: Neurobiological mechanisms of anhedonia. Dialogues Clin Neurosci 2008, 10(3):291-9.

44. Zurita A, Martijena I, Cuadra G, Brandão ML, Molina VA: Early exposure to chronic variable stress facilitates the occurrence of anhedonia and anhanced emotional reactions to novel stressors: reversal by naltrexone. Behav Brain Res 117:163-171.

45. Dantzer R, Kelley KW: Twenty years of research on cytokine-induced sickness behavior. Brain Behav Immun 2007, 21:153-160.

46. Miller DB, O'Callaghan JP: Depression, cytokines, and glial function. Metabolism 2005, 54:33-38.

47. Dellagioia N, Hannestad J: A critical review of human endotoxina administration as an experimental paradigm of depression. Neurosci Biobehav Rev 2010, 34:130-43.

48. Chang Y, Lee JJ, Hsieh CY, Hsiao G, Chou DS, Sheu JR: Inhibitory effects of ketamine on lipopolysaccharide-induced microglial activation. Mediators Inflamm 2009, 2009:775-379.
49. Sheline Yl, Sanghavi M, Mintun MA, Gado MH: Depression duration but not age predicts hippocampal volume loss in medically helthy women with recurrent major depression. J Neurosci 1999, 19(12):5034-43.

50. Duman RS, Monteggia LM: A neutrophic model for stress-related mood disorders. Biol Psychiatry 2006, 59(12):1116-27.

51. Siuciak JA, Lewis DR, Wiegand SJ, Lindsay RM: Antidepressant-like effect of brain-derived neurotrophic factor (BDNF). Pharmacol Biochem Behav 1997. 56(1):131-7.

52. Shirayama $Y$, Chen AC, Nakagawa R, Russel DS, Duman RS: Brain-derived neurotrophic factor produces antidepressant effects in behavioral models of depression. J Neurosci 2002, 54(7):597-606.

53. Duman RS, Heninger GR, Nestler EJ: A molecular and cellular theory of depression. Arch Gen Psychiatry 1997, 54(7):597-606.

54. Bilbo SD, Schwarz JM: Early-life programming of later-life brain and behavior: a critical role for the immune system. Front Behav Neurosci 2009, 3:1-14.

55. Himmerich H, Fulda S, Linseisen J, Seiler H, Wolfram G, Himmerich S, Gedrich K, Kloiber S, Lucae S, Ising M, Uhr M, Holsboer F, Pollmächer T: Depression, comorbidities and the TNF-alpha system. Eur Psychiatry 2008, 23:421-429.

56. Grassi-Oliveira R, Brietzke E, Pezzi JC, Lopes RP, Teixeira AL, Bauer ME: Increased soluble tumor necrosis factor-alpha receptors in patients with major depressive disorder. Psychiatry Clin Neurosci 2009, 63:202-208.

57. Soczynska JK, Kennedy SH, Goldstein Bl, Lachowski A, Woldevohannes HO, McIntyre RS: The effect of tumor necrosis factor antagonists on mood and metal health-associated quality of life: novel hypothesis-driven treatments for bipolar depression? Neurotoxicology 2009, 30:497-521.

58. Banks WA: Physiology and pathology of the blood-brain barrier: implications for microbial pathogenesis, drug delivery and neurodegenerative disorders. J Neurovirol 1999, 5:538-555.

59. Stamatovic SM, Dimitrijevic OB, Keep RF, Andjelkovic AV: Inflammation and brain edema: new insights into the role of chemokines and their receptors. Acta Neurochir 2006, 96:444-450.

60. Raslan F, Schwarz T, Meuth SG, Austinat M, Bader M, Renné T, Roosen K, Stoll G, Sirén AL, Kleinschnitz C: Inhibition of bradykinin receptor B1 protects mice from focal brain injury by reducing blood-brain barrier leakage and inflammation. J Cereb Blood Flow Me 2010.

doi:10.1186/1742-2094-7-98

Cite this article as: Viana et al:: Kinin $B_{1}$ receptors mediate depressionlike behavior response in stressed mice treated with systemic $E$. coli lipopolysaccharide. Journal of Neuroinflammation 2010 7:98.

\section{Submit your next manuscript to BioMed Central and take full advantage of:}

- Convenient online submission

- Thorough peer review

- No space constraints or color figure charges

- Immediate publication on acceptance

- Inclusion in PubMed, CAS, Scopus and Google Scholar

- Research which is freely available for redistribution

Submit your manuscript at www.biomedcentral.com/submit
C Biomed Central 